\title{
ON SOME NEW OR HITHERTO LITTLE KNOWN LAND SHELLS FROM NEW GUINEA OR
} ADJACENT ISLANDS.

By C. F. Ancey, Administrateur-adjoint, Dra-el-Mizan, Algeria.

\section{(Communicated by C. Hedley.) \\ (Plate xxvi.)}

Some time ago I received from a German dealer, under probably unpublished names, the following land shells belonging to the Papuan fauna. Although the exact localities of most of them are unknown, they are, I think, from the German possessions of New Guinea.

1. Papuina Hedleyi, E. A. Smith.

(Fig. 1.)

Helix (Geotrochus) Hedleyi, Smith, Journ. of Conchology, Vol. vii. 1892 , p. $72,=$ Helix Canefriana, Dohrn, Cat. Staudinger (unpublished).*

I take the opportunity of giving a figure of this little known and very remarkable form from a specimen in my possession. Smith's description applies perfectly well to it, and the dimensions given are just the same. My unique specimen appears, however, to be of a darker colour, and the aperture is dark within; the tuberculous columella is stained with pale violet or white in this example, and the infra-sutural line is conspicuous in the penultimate whorl as well as on the last, but fades on the upper ones. I failed to detect any spiral impressed lines on the surface of the

* This synonymy is supported by Sykes. Journal of Malacology IV. p. 51 [C.H.] 
body whorl, which is, as Mr. Smith remarks, an individual rather than specific character.

Loc.-(German?) New Guinea, fide O. Staudinger.

Judging from its affinities, Mr. Smith declared it to come from New Guinea; this statement is confirmed here.

\section{Papuina Tuomensis, n.sp.}

Helix Tuomensis, Bttg., Cat. Staudinger (unpublished ?).

\section{(Plate xxvi., Fig. 3.)}

Testa imperforata, depresso-conica, subtrochiformis, sat tenuis, nitida, superne tenuissime spiraliter striata, prope aperturam lineis obsoletis et parum regularibus, antrorsum oblique descendentibus exarata, subtus lineis spiralibus undulatis exiliter rugosa. Spira late conica, summo lævi, obtuso, concolore. Anfractus $4 \frac{1}{2}$, convexi, sutura lineari, parum impressa; ultimus magnus, rotundatus, initio vix subangulatus, infra convexus, antice breviter et subito deflexus. Apertura obliqua, sinuata, diagonalis, nigrolimbata, margine supero sinuato, tum extus impresso et interne late subtuberculato, extero obtuse rostratim producto, columellari lato, appresso, oblique in lineam rectam inflexo, ad finem obsolete tuberculifero. Peristoma reflexum, nigrum (pariete aperturali albo). Supra griseo albida, dehinc in penultimo anfractu alba, deinde flavida, circa umbilici regionem albescens. Ultimus anfractus atro-castaneo bizonatus in medio, zona supera in penultimo prolongata, præteria fascia exiliore suturali ejusdem coloris exornatus.

Diam. maj. $23 \frac{1}{2}$, min. $18 \frac{1}{2}$, alt. 15 mill.

\section{var. HETEROCHROA.}

\section{(Plate xxvi., Fig. 4.)}

Paulo minor (diam. maj. $22 \frac{1}{2}$, min. $18 \frac{1}{2}$, alt. $15 \frac{1}{2}$ ) et globosior, lineis tantum incrementi obliquis obsolete striatula, multo nitidior, micans; superne pulchre roseo-purpurea; ultimus anfractus læte flavidus medio basique albicans, præter vestigium fasciæ suturalis et maculis duabus castaneis prope aperturam efasciata, his, sicut 
ac in typo, in apertura transmeantibus. Paries aperturalis pallide roseus.

var. VIOLACEO-FLAVA.

Præcedenti statura forma et absentia sculpturæ similis, sed typo fasciis vicina. Superne atro-violacea, dehinc pallidior, denique late flava, fasciis 2 periphericis ornatæ, supera latiore, suturali prope aperturam tantum conspicua, mox evanescenti. Paries aperturalis et pars ultimi infra purpureo tincta.

Loc._- "Tuom," probably in German New Guinea, or Bismarck Archipelago. From the same locality I received at the same time Helicina suprafasciata, Sowerby.

Shell imperforate, trochiform, rather thin. Spire conic, obtuse. Whorls less than 5, convex, regularly increasing, suture linear, simple; the last one large, rounded at the periphery. Sculpture faint, obsolete growth lines slightly decussated by fine crowded lines, spirally impressed above and below (where they become somewhat wavy and irregular), and obliquely running towards the aperture on the upper part of the last whorl. Surface more shining in the varieties, differing also from the type in being entirely smooth or nearly so, the only sculpture consisting in obsolete growth lines, and in colour. The whorls also appear to be a trifle more convex. Colour (in the type) greyish above, fading into milky white and finally into intense yellow on the last whorl; the latter is, on its middle, ornamented with two broad chestnut-black zones, the upper one extending on the penultimate whorl; painted besides with a finer sutural band of the same hue, also ascending on the penultimate. All these bands are conspicuous in the interior of aperture. The latter is diagonal, shortly and abruptly deflected in front. Lip intense black, reflected, roundly beaked at the periphery, flexuous above, then dented without and somewhat tuberculate within. Columella broad, adherent to the base, very slightly tuberculous at the end on the inner edge.

This interesting novelty belongs, like the following species, to the group of Papuina Tayloriana, Ad. and Reeve, but is destitute of any carina on the last whorl, and recalls to mind Papuina 
Millicentce, Cox, from the Louisiades, which has nearly the same form, but not the same style of colouring.

\section{Papuina Kubaryi, Möllendorff.}

Helix Kubaryi, von Möll., Cat. Staudinger.

$$
\text { (Plate xxvi., Fig. 5.) }
$$

Testa imperforata, depresso-conica, subtrochiformis, modice solida, subnitida, undique tenuissime rugulosa, rugulis, irregularibus, infra dispositionem spiralem præbentibus. Spira late conoidea, summo minuto, obtuso, lævi. Anfractus $4 \frac{1}{4}$, convexi, sutura lineari impressaque divisi, celeriter accrescentes, ultimus magnus, rotundatus, initio obscure angulatus, infra convexus, antice haud abrupte deflexus. Apertura obliqua, sinuata, extus rostrata (rostro sat minuto, erecto obtuso), nigrolimbata, diagonalis, margine supero leviter lateque sinuato, tum extus subimpresso, dehinc in rostrum prolongato; columellaris appressus, mediocris, oblique in lineam rectam declivis, haud tuberculatus, cum basali arcuato absque angulo junctus. Peristoma supra anguste, basi magis reflexum et expansum, atrum. Paries aperturalis violaceus. Apex nigro-violaceus; anfractus supremi grisei, inferne (ad suturam) late purpurei, penultimus pallide stramineus, punctis et lineis griseo-pellucidis adspersus; ultimus prope aperturam pulchre luteus, pone peristoma carneo-rubellus, seriebus 2 punctorum seu macularum nigrorum in fascias dispositis et plus minusve in penultimo evanescentibus egregie picta. Faux fuscula, fasciis transmeantibus.

(a) Diam. maj. 25, min. 19, alt. 16 mill.

(b) Diam. maj. $23 \frac{1}{2}$, min. 18 , alt. 15 mill.

\section{var. ALBIDA.}

Testa lactea, concolor, peristomate albo, griseo exiliter rare passimque substrigata vel punctulata, cæterum typo simillima.

Diam. maj. 25, min. 20, alt. 17 mill.

Loc._(German ?) New Guinea. 
This very pretty and interesting Papuina is evidently very close to Mr. Brazier's Helix Gorenduensis (Proc. Linn. Soc. New South Wales, 3rd April, 1886, p. 841), and I first thought they might be identical. However, Papuina Kubaryi has not 5 whorls, and, judging from Mr. Brazier's description, also differs in several other particulars. No mention is made by the latter of the disposition of the small spots, which, in Gorenduensis, are "pinkish," not grey nor blackish towards the aperture. Mr. Brazier says his shell is "flesh-tinted a cream colour," while Kubaryi is yellowish cream-colour, reddish-pink behind the peristome. The aperture, in this, is intense black on the lip, violet-purple on the parietal margin, and purple-brown within the throat, while in Gorenduensis, "the interior is bright pink, the peristome blackish-purple," and the "margins joined with a thin pink callous entering spirally into the interior of the aperture." I therefore suppose the two species are really different from each other.

\section{Hemiplecta granigera, n.sp.}

Testa subsolida, depressa, orbiculata, aperte umbilicata, oblique confertim striata et undique minute spiraliter granulata (granulis in ultimo validioribus, circa umbilicum magis obsoletis), vix nitida, sordide fusca, medio obtuse angulata, infra angulum zona obscuriore per testam conspicua diffusaque cincta, subtus pallidior. Spira depresso-conoidea, obtusa. Anfractus 6 subconvexi, sutura parum profunda, simplici; ultimus haud descendens, superne et præsertim infra angulum medianum obtusum pallidum convexus. Apertura ampla, obliqua, lunata, transverse subovalis. Peristoma simplex, acutum, rectum, marginibus remotis, callo tenui nitido concolore junctis, margine columellari late arcuato, vix expansiusculo, umbilicum (pro genere magnum, anfractus omnes ostendentem) nullomodo obtegente.

Diam. maj. 43, min. 35, alt. 22 mill.

Loc.-(German?) New Guinea.

This species should perhaps be referable to Rhysota, but is more nearly related, from the general appearance of the shell, to 
such Hemiplecta as Blainvilleana, Humphreysiana and Fouilloyi. I received it under the latter name, but it is certainly utterly distinct. The Fouilloyi is a large and more globose shell, more narrowly umbilicated. In this respect the present shell is more like Rhysota Achilles, Braz., but is smaller, has a thin aperture and more numerous volutions. The sculpture may be the same in both species.

\section{Pupina Beddonei, n.sp.}

\section{Pupina Beddomei, Bttg., Cat. Staudinger.}

Testa ovata, tenuis, pellucida, hyalina, nitidissima, griseoalbicans. Spira oblonga, obtusiuscula; anfractus 6 levissime convexi, sutura callosa zona exili pellucida cincta divisi; ultimus descendens, ad aperturam breviter ascendens, antice subdepressus. Apertura basi antice provecta, rotundata, bicanaliculata, scilicet; canali supero peristomate non extus exciso et lamina parietali arcuata sat valida intrante constituto, et canali altero ad basin columellæ excisæ, extus in foramen rotundatum terminato. Peristoma intus incrassatum, leviter patulum.

Long. 7, diam. $3 \frac{1}{2}$; long. apert. $2 \frac{2}{3}$ mill.

Loc.-Bismarck (or New Britain) Archipelago.

This species is more slender than Pupina speculum, TapparoneCanefri (Fauna Malac. Della Nuova Guinea, 1883, p. 270, Pl. x. figs. 14-15), and indeed more nearly related to Pupina difficilis, Semper, of the Pelew Islands. From the last named species it differs in being a trifle larger, light ash-coloured, and chiefly in the characters of the aperture, which is vertical in difficilis, also furnished with a more robust superior lamina and more excised columellar margin in Pupina Beddomei. The same characters, although not very striking, will also without much difficulty distinguish Pupina Beddomei from the complanata, Pease, which occurs in the Kingsmill and Caroline groups. They are very constant in the several specimens before me.

I am happy to give this species the name of my distinguished correspondent Mr. C. E. Beddome. 


\section{Cyclophorus Kubaryi, Möllendorff.}

Cycl.phorus Kubaryi, v. Möll., Cat. Staudinger.

\section{(Plate xxvi., Fig. 6.)}

Testa solida, opaca, rugosa, parum nitens, turbinato-globosa, profunde sed (pro genere) minute umbilicata, umbilicus ad terminationem leviter excentricus, superne atro-fusca, in medio ultimi anfractus luteo plus minusve distincte bifasciata, subtus circa umbilicum flava vel pallida. Spira conoidea, elevata, obtusa. Anfractus $5 \frac{1}{4}$, convexi, sutura infra subirregulari discreti, haud valde turgidi; ultimus relative (pro genere) parum amplus, rotundatus, altus, prope aperturam leviter subdeflexus. Apertura subobliqua, fere circularis, ad insertionem subangulata, extus leviter sinuata, sordide lutea. Peristoma acutum, haud expansum nec reflexum, vix patulum, ad columellam paulo magis incrassatum et expansiusculum, umbilicum haud tegens. Lineis incrementi sub lente irregulariter exarata et rugis undulatis ad apicem evanescentibus, basi tenuioribus peculiariter et eximie sculpturata, quasi vermiculata. Operculum tenue, rubellum, multispiratum, centro minute concavum.

Diam. maj. 28, min. 23, alt. 24, alt. apert. 14 mill.

Loc.-(German?) New Guinea.

There is no form known to me that I might compare with this. The operculum is red, thin and cyclophoroid, while the shell itself resembles in shape, as far as I can suppose from the figure given by Mr. M. M. Schepman, Cyclotus Soembaensis, of the Island of Soemba (Indian Archipelago). The description of the latter applies nevertheless to a true Cyclotus of the section I'seudocyclophorus, Martens. (See Notes from the Leyden Museum, Vol. xiv. p. 158, Pl. 6, fig 3, 1892.) The remarkable sculpture of Cyclophorus Kubaryi is quite peculiar for the genus as well as the general "lout ensemble" of the shell, and the simple, not reflected, lip. The former, obsolete beneath, is very much marked above, and recalls that of Helix Quoyi and mamilla, although it may be termed as more vermiculous. The whorls are more tightly 
coiled and the apex more globular, less mamillar than in any Cyclophorus I am acquainted with. No shell from New Guinea is like this, and I feel confident altogether that when the animal is known it may be considered the type of a new genus. Provisionally, a sectional name may be given to it, and I should propose for this object that of Papuocyclus, as the only species known till now of this section belongs to the Papuan fauna. To my knowledge the large typical Cyclophori are still unknown from New Guinea or neighbouring isles.-Algeria, Feb. 1st, 1895.

\section{EXPLANATION OF PLATE.}

Fig. 1.-Hemiplecta granigera, Ancey.

Fig. 2.--Papuina Hedleyi, Smith.

Fig. 3.- ,, tuomensis, Ancey.

Fig. 4.- , , , var. heterochroa, Ancey.

Fig. 5.— , Kubaryi, Möllendorff.

Fig. 6.-Cyclophorus Kubaryi, Möllendorff.

\section{Note by C. Hedley.}

About the date on which I received the manuscript of the above, there reached me an article by Dr. O. von Möllendorff, "On a Collection of Land Shells made by Mr. I. Kubary in German New Guinea," Proc. Malac. Soc. Vol. I. Pt. V. Pl. xv. pp. 234-240. Dealing with similar material, Mr. Ancey's paper has been partially anticipated by the prior descriptions of $P$. and C. Kubaryi. Since, however, Mr. Ancey's independent observations extend beyond those of his predecessor, and since the intervention of time and space do not allow me to refer the paper back to the author, I have judged it best to offer it intact to the Society. 


\section{$2 \mathrm{BHL}$ Biodiversity Heritage Library}

Ancey, C. F. 1895. "On some new and hitherto little known land shells from New Guinea or adjacent islands." Proceedings of the Linnean Society of New South Wales 10, 374-381. https://doi.org/10.5962/bhl.part.24352.

View This Item Online: https://www.biodiversitylibrary.org/item/30097

DOI: https://doi.org/10.5962/bhl.part.24352

Permalink: https://www.biodiversitylibrary.org/partpdf/24352

\section{Holding Institution}

MBLWHOI Library

\section{Sponsored by}

MBLWHOI Library

\section{Copyright \& Reuse}

Copyright Status: NOT_IN_COPYRIGHT

This document was created from content at the Biodiversity Heritage Library, the world's largest open access digital library for biodiversity literature and archives. Visit BHL at https://www.biodiversitylibrary.org. 